Illinois State University

ISU ReD: Research and eData

Faculty and Staff Publications - Milner Library

Milner Library

2006

\title{
Re-visioning Information Literacy for Lifelong Meaning
}

Dane Ward

Illinois State University, dmward@ilstu.edu

Follow this and additional works at: https://ir.library.illinoisstate.edu/fpml

Part of the Education Commons, and the Library and Information Science Commons

\section{Recommended Citation}

Ward, Dane, "Re-visioning Information Literacy for Lifelong Meaning" (2006). Faculty and Staff Publications - Milner Library. 38. https://ir.library.illinoisstate.edu/fpml/38

This Article is brought to you for free and open access by the Milner Library at ISU ReD: Research and eData. It has been accepted for inclusion in Faculty and Staff Publications - Milner Library by an authorized administrator of ISU ReD: Research and eData. For more information, please contact ISUReD@ilstu.edu. 


\title{
Re-Visioning Information Literacy for Lifelong Meaning
}

\author{
By Dane Ward \\ Illinois State University \\ dmward@ilstu.edu
}




\begin{abstract}
Information literacy is a broader capacity than current practices would suggest. In addition to critical thinking, information literacy includes information processes that explicitly address meaning, motivation and the quality of life. A more robust notion of the concept delivers significant opportunities for libraries and instructional programs.
\end{abstract}

\title{
Introduction
}

How do we understand a poem, a work of art, or a piece of music? Is it enough to be able to find, evaluate, and use information about Beethoven's Seventh Symphony to demonstrate basic information literacy? Or does that capacity consist of something more? Beethoven expected more from us than an analysis of his work; he expected us to be affected and transformed by it.

Critical thinking is not always sufficient in itself as a strategy for navigating through the information universe. Being information literate requires more than the ability to work analytically with information. It also demands that we know how to manage information in more creative and meaningful ways. Growth in reflection and self-knowledge, for instance, is just as important as critical thinking to the development of information literacy. The two sides complement each other and are inextricably linked.

Information literacy consists of a broader array of competencies than our instructional practices and competency standards would suggest. After all, information, the fundamental substance of this competency, is pervasive. We are immersed in an information ocean like fish in water. Somewhat oblivious to the many ways we interact with it, we receive it steadily through the senses and through intuition. We process it individually and collectively, subjectively, objectively, emotionally and analytically. 
This more comprehensive notion of information carries tremendous implications for our understanding and teaching of information literacy. Instead of being the only framework for navigating the information universe, critical thinking is just one of many. This conceptualization would dictate that as librarians and faculty, we devote as much attention to helping students make a personal connection to a topic as we do to the analytical aspects of conducting research and generating a paper or presentation. We must help them find and comprehend the ageless wisdom available through our libraries, regardless of its format or form as parable, poetry or indigenous knowledge.

\section{Definitions of Information Literacy}

In 1989, the Final Report of the American Library Association Presidential Report on Information Literacy stated that "to be information literate a person must be able to recognize when information is needed and have the ability to locate, evaluate, and use effectively the needed information."1 After more than fifteen years, that definition still holds water. It describes quite well a research process based on the use of empirical information. Students come to the reference desk seeking help with their research, often framed as a search for information. They ask for help discovering the major agricultural product of Senegal, or articles about the United States' plans to fight AIDS in Africa.

Teaching students to think critically about information is a fundamental goal of information literacy instruction, as it should be. Without a well-developed capacity to evaluate and use information from books, library databases, or the Internet, students make questionable decisions, and sometimes about very important matters. The lack of adequately developed information skills among a nation's citizens hinders the successful 
functioning of democracy and decision-making for the common good. Poor information skills by local, state, and national leaders can result in tragic, unfortunate consequences.

Over the last ten years, librarians and others have built on the 1989 definition and taken great strides in defining information literacy. In 2001, the Association for College and Research Libraries' (ACRL) Competency Standards for Information Literacy (2001) established five standards, 71 objectives and 141 measurable performance indicators. ${ }^{2}$ Following soon after, an ACRL task force produced Characteristics of Information Literacy Programs Demonstrating Best Practices which articulated the necessary programmatic elements of information literacy instruction. ${ }^{3}$

Nevertheless, definitional issues have plagued the concept for years. Other terms, essentially indistinguishable from information literacy, have included information competence, information and communication technology literacy, evidence-based practice, resource-based learning and media literacy. Some distinctions between terms seem to be a matter of semantics. Others would seem to represent examples of information literacy within specific subject disciplines or applied to specific resources.

In 1997, Snavely and Cooper wondered whether "all those in academe who use the term information literacy use it in the same way?" ${ }^{4}$ Nearly ten years later, a quick review of literature reveals that even librarians do not use it in a similar fashion. Many of us still think of it as a synonym for the kind of understanding that results from library instruction. Others hold fast to the idea that information literacy involves much broader information-management skills. This latter group maintains that the teaching of information literacy is part of an educational reform movement involving a paradigm shift from teaching to learning as described, for instance, by Barr and Tagg. ${ }^{5}$ Students do 
not achieve information literacy by attending one or more library sessions. Rather, students learn relevant information skills when they are systematically integrated and sequenced throughout the curriculum.

Perhaps however, these differences represent merely the tip of an information literacy iceberg. The larger and more substantive distinction has not been addressed. We have worked hard to define the concept in order to eliminate endless misunderstandings among our colleagues and potential collaborators. However, in defining it as we have in terms of a concrete, verifiable competency, we have risked diminishing a vast and mysterious information universe to one known only through logic and critical analysis.

\section{Broader Notions of Information Literacy}

The 1989 definition of information literacy and the subsequent efforts to provide concrete examples would seem to put an end to the discussion. However, those clarifications are a little like the glass that is half full. The definition leads us to see what's there, but not what's missing. Perhaps our emphasis on critical thinking about information is not an adequate response to the complex information universe in which we live. Our relationship to information is much more complicated than that. We understand our selves and the world in other ways as well. Information comes to us in many forms, including metaphor, poetry, literature, and myth. We use psychological processes of intuition and imagination as much as critical thinking to mediate our relationship to the world.

Personal, interior experiences of information are fundamental to a vital information literacy that can make a difference in our lives and in the world. We must not take this for granted. The information universe exists within us as much as it does beyond 
us. The difference between critical thinking and more personal understandings of information is depicted in the movie Good Will Hunting. The main character, a brilliant young man with a remarkable memory and capacity to synthesize information, would seem to be information literate. However, through a conversation with his therapist, we get a hint that Will knows a great deal about one side of information, but not the other:

"So, if I asked you about art you'd probably give me the skinny on every art book ever written," says Sean, his therapist. "Michelangelo, you know a lot about him-life's work, political aspirations, him and the Pope, sexual orientation, the whole works, right? But I bet you can't tell me what it smells like in the Sistine Chapel. You've never actually stood there, and looked at that beautiful ceiling." 6

Can information literacy be limited to one, but not the other, realm of information? Can we be information literate if we possess the technical ability to find and evaluate information, but not the human capacity to experience and value it? Can we be committed to an issue if it fails to resonate with anything within us? I would argue that information literacy requires a more balanced approach to information. We cannot be truly information literate without cultivating both aspects of information literacy. Information literacy is not a static and limited idea, but a dynamic concept that continues to grow to incorporate a larger set of skills essential for a life of meaning in an information era. We have, to date, defined one aspect of information literacy, but have hardly begun to explore the other.

In their visionary 1996 article "Information Literacy as a Liberal Art," Shapiro and Hughes stated that our goal should be nothing less than to teach what it means to be a free person in the Information Age. Relevant information skills are those that permit us 
to navigate the Web and to understand more fully how our lives are shaped by the information and information choices we are given. Information literacy is a revolutionary tool that empowers each of us to take bold steps in determining the course of our lives, and to take actions that benefit the greater good. Shapiro and Hughes have presented us with an ambitious challenge, one that remains unmet by current instructional practice.

\section{The Other Side of Information Literacy}

Information literacy as a liberal art would hold us to a higher standard. It would have us teach students more holistically, connecting not only to their analytic mind, but also to their imaginative mind. It is not enough for students to learn how to think critically about information for a research paper. They must learn how to be engaged and why to care. These latter information skills must be cultivated at the same time as those with which we are more familiar. I predict that the future of information literacy instruction will increasingly emphasize other ways of understanding information, and that this will include teaching students about personal engagement and self-knowledge.

Certainly, information literacy encompasses a domain of knowledge that consists of critical thinking about information. This includes applying criteria for evaluating web sites and articles found in databases, as well as logic in assessing arguments. However, information literacy also includes the imagination of information, our deepening experience of it, and appreciation for the richness of that vast reservoir of meaning and interior life. To imagine or create mental images in response to information is to bring to consciousness something of our own, something from the depths of our psychic life, and to have a connection to it. 
Consider the typical problem noted by librarians and instructional faculty of students failing to become engaged in the library session or the course content. This is discussed as a problem of engagement. I would argue that it is a problem of information literacy, a failure on our part to address a fundamental information issue - the necessity of addressing both sides of our interaction with a complex information universe.

Information comes to us both from the outside and from the inside. On one hand, we receive the external world through the five senses. We see the citation. We hear the lecture. We touch the keyboard. This type of information is fundamental in research, both in school and in real life. Defensible research is based on objective, empirical data. Other researchers can verify our conclusions. Information literacy instruction, in its emphasis on critical thinking about information, values this type of information. This is what Dirkx calls a "technical-rational view of knowledge;" it stresses a process of instrumental learning that permits us to "adapt to the demands of our outer environment." 8

On the other hand, information also comes to us from within, for instance through intuition, imagination and reflection. "What do you see when you turn out the lights?" wonders the vocalist in With a Little Help from My Friends: "I can't tell you, but I know it's mine." 9 Our awareness is constantly receiving information that comes from our inwardness; it is personal, non-rational, and non-verifiable by others. But most importantly, it is meaningful because it comes from within; it is who we are. We hear our inner voice in dreams or in stillness. Many poets, philosophers and psychologists give precedence to this inward realm of information. Neil Baldwin, biographer of William Carlos Williams, reminds us of the poet's words: "only the imagination is real." 10 
We continually experience the world of inner information. It comes to us in nighttime dreams and daytime reveries. We know it through the images, hopes and emotions that are sparked by music, poetry and performing art. As psychologist James Hillman states, "images are where the psyche is." ${ }^{11}$ We discover and connect to the world from the inside out. Our responses to world poverty for instance results from our ability or inability to empathize with those who suffer; it requires us to personalize rather than objectify their experience, to see the images and hear the voices of the world as they resonate within us. To make a difference in the world requires that we care about it, that we step beyond a passive acceptance of life. As librarians and faculty, we must teach this other side of information. It is a fundamental responsibility for us as educators to embrace a commitment to a more holistic information literacy that can make a difference in the world. The world cries for it. But how do we teach it?

\section{Loving the Question}

Rainer Maria Rilke once advised an aspiring poet "to be patient toward all that is unsolved in your heart and to try to love the questions themselves...Live the questions now. Perhaps you will then gradually, without noticing it, live...into the answer." ${ }^{12}$ To teach students about personally meaningful information and non-analytic information processes means first and foremost to create a space where the inner life can be nurtured, where creativity can emerge, where students can love the questions. Librarians and teachers must design information literacy instruction that that permits this possibility.

Rilke emphasizes the importance of not jumping too quickly to the answers. More important than any immediate solution is the broader goal of integrating questions into our lives, holding them close without jumping to closure. By doing so, we enter into 
wonder, possibility and imagination. We discover the complexity and subtlety of an infinitely mysterious world. Information literacy is not a set of competencies; it is a way of being that comes from living the question.

Librarians and faculty can also teach students about their inwardness by providing opportunities for self-understanding, and by consciously facilitating their development as lifelong learners. Tools such as the Myers Briggs Type Indicator (MBTI) can help students learn about their research preferences, especially with regards to gathering information and processing it. I have administered the MBTI in research courses and found that it marvelously complements traditional library and information literacy instruction.

Librarians have correctly claimed a special relationship between information literacy and lifelong learning. The authors of ACRL's Information Literacy Competency Standards state that "information literacy forms the basis for lifelong learning." ${ }^{13}$ But that document, which emphasizes a more technical and rational relationship to the world, fails to examine the inward roots of lifelong learning. To be more than a reactive learner requires curiosity, intrinsic motivation, and the willingness to love the question. The critical thinking skills associated with information literacy do not produce lifelong learning. They are probably a necessary prerequisite, but not a guarantee of this capacity.

A robust conceptualization of information literacy must recognize the inextricably linked aspects of information — the one derived from an external, verifiable reality and the other from an internal, more subjective reality. Life in this era of superabundant information requires that we both think critically about a problem while also bringing our authentic, engaged selves to the task. Neither source of information will suffice in 
isolation. Academic research questions also involve working with both types of information. By facilitating information literacy work within both domains and emphasizing their interdependence we can bring about powerful learning experiences. Sociologist Richard Quinney exemplifies this approach to information. "I tell my students in the Peace and Social Justice course that to know the subject we must become one with it, and that in the process of knowing we will be transformed." 14

Through the experience of robust information literacy instruction, students touch the world deeply through their research questions and are touched by it as well. Transformed by the process, they become willing and able to transform the world. The two sides of information are deeply interconnected, the internal and the external. Reality is not something "out there," separate from our selves. It is constructed through interaction with others and with our selves.

\section{An Example of Re-Visioned Information Literacy Instruction}

What would our instruction look like if it were based on a robust, holistic model of information literacy? Most notably, we would see a much greater variety of information-related activities, requiring a more diverse expertise on the part of the instructors. At the same time, the library would play an even more prominent part than it does now. In this environment, deep levels of collaboration between librarians, faculty and other campus services would be the norm for teaching and learning.

Let's assume that we are working with a faculty member, say Richard Quinney, and his Peace and Social Justice class. Our collaboration revolves around facilitating students' acquisition of information skills, enabling them on one level to conduct effective research. We want students to successfully define a research topic, find 
information, evaluate it, and use it in a meaningful research paper. At the same time, in addition to mastering these instrumental research skills, we want them to become deeply engaged in their topic. This is not research for the sake of practice research, but for making a difference.

The entire process of working together and with the students requires us to carefully integrate the two sides of information literacy into a research project. To facilitate the initial stage of research--in particular defining a research topic--we must bring the topic into a relationship with the students and their inwardness. Superficially, this could mean introducing students to a topic and providing some background information. More profoundly, it means stepping beyond rational processes of exposition and into ways of knowing that reaches out to our inwardness. In this instance, we introduce music, images and performance about social injustice in the classroom, and facilitate far-reaching discussions. We also provide students with the chance to express affective responses through creative drawing, and asking them to share with others something of the meaning that they see or had intended.

Perhaps most importantly, we take the time to create an environment where students and instructors feel free to express their thoughts and opinions, be they logical, creative, or even unformed. As a group, it is necessary that we build the community of truth that Parker Palmer talks about. ${ }^{15}$ We must encourage sharing and self-disclosure, so that students grow personally as well as academically. That goes for us as well. Life is messy, and we all have plenty to share about our experiences. We can tap deeply into our inner worlds and connect with a world beyond our immediate grasp. Truth emerges when we can speak with each other trustfully, bringing forward our true authenticity. 
On the rational-technical side of information literacy, we teach students to conduct effective research in library databases. However, recognizing that effectiveness involves self-knowledge as much as tangible skill, we provide students with the opportunity to explore their personality preferences for research. Sometimes difficulty finding verifiable facts may result, not from a lack of skill, but from a preference for different types of information. Various assessment instruments can be used to provide insights about such preferences.

The MBTI, for instance, focuses on personal preferences along four spectrums of functioning, each with implications related to research. On one side of the spectrum that assesses one's preference for gathering information, the MBTI indicates that some people would rather obtain detailed, concrete information through the five senses. Others want information to come to them as connected "big-pictures" information through more intuitive processes. Students with the former preference will easily find large amounts of high-quality authoritative information, but may struggle to develop a significant research question. Students with the latter preference intuitively "understand" the question, though they may not appreciate why it requires research support, or what exactly needs support.

Applying MBTI distinctions throughout the course can have tremendous impact on student learning and group process. Students will not only understand how to enhance their research skills, but they will also begin to understand other students, and why some of them seem so difficult or foreign. By having access to this inner information, they become more competent in the outer world, and more fully information literate. 


\section{Towards Re-Evaluation}

In teaching students about evaluation, we proceed in a familiar manner apply criteria in assessing web sites, lists of citations, and the scholarly quality of specific articles. However, we also explore evaluative processes based on non-analytic methods and systems for distinguishing quality and truth because in real life, we do not evaluate everything in terms of impersonal logic.

Other criterion may be based on values, qualities, emotions and world-views. For instance, why did you and your friends go out to see a particular movie? Was it because you liked an actor, preferred romance to violence, or wanted to see something spiritually uplifting? These are all non-rational criteria, though certainly more meaningful.

Being information literate means having the capacity to apply different systems of evaluation for different information needs. The Trappist monk Thomas Merton once attended a jazz concert where he sat next to someone with a limited set evaluative tools. The individual could hear the music, but didn't possess a cognitive framework that would allow him to assess the music. So he tried to analyzed it, asking Merton to do so as well:

"One man kept asking me to justify it, explain what could possibly be good about it, instead of listening to it. Still, it was good...Power and seriousness of the jazz. As if they were playing for their own sake and for the sound's sake and had no relationship to the people around them. And yet for the most part everyone seemed to like it. Without understanding that here was one place in Louisville where something was definitely being done and said." 16

What kind of evaluative criteria did Merton have? We hear Rilke here telling us to love the question... or music in this case. Don't analyze it. Listen. We also get a hint of 
Merton's criteria based on his years of exposure to jazz and preferences: power, seriousness, music for its own sake, the recognition that something important was being expressed. His observations require us to open ourselves to evaluative processes that cannot be quantified or pigeon-holed. To appreciate his assessment, we must reach out and empathize with his observations. We are asked to live the question as well.

Merton's example highlights the problem of singularly applying critical thinking to all research questions. By doing so, we risk failing to come to grips with the mystery and wonder of the world, instead reducing it to something flat and meaningless.

More concretely, we jumpstart a conversation in the Peace and Social Justice class about different evaluative systems by listening to the Black Eyed Peas song "Where is the Love." Highlighting a real-world information literacy issue, the song provokes us to consider the paradox of valuing human compassion and yet contributing, albeit indirectly, to the creation of a culture that hurts our fellow humans:

"Wrong information always shown by the media Negative images is the main criteria Infecting the young minds faster than bacteria Kids wanna act like what they see in the cinema Yo', whatever happened to the values of humanity Whatever happened to the fairness in equality Instead of spreading love we spreading animosity Lack of understanding, leading lives away from unity" ${ }^{17}$

We begin the discussion by offering a critical analysis of the lyrics. What is the argument here? Is it supported by facts? What assertions are made? That the media gives 
wrong information and that it is more interested in sensationalizing and selling information than it is in its veracity? Does this information impact children in a negative way? From an analytic perspective, the song raises questions but no authoritative facts. We might disqualify this information source because it doesn't deliver hard evidence.

However, we go further. The song possesses an emotional appeal as well by bringing people-focused values to our attention. It touches our hearts. By pointing out the disparity between our desire for a better world and a familiar reality that harms it, the lyrics reach out to us, bridging the gap between our inward experience and the external world. Some students will find the emotional argument very appealing. Is it invalid because it is not supported by facts? No, it has validity in so far as it has meaning to us.

The emotional argument comes from an alternative evaluative system. The value of an emotional appeal depends on the information need. Are we trying to establish the fact that the media impacts children negatively, or are we trying to raise awareness and concern for the world in which we live? If the former, it probably does not succeed, but if latter, if most certainly does. Information literacy requires both ways of knowing.

\section{Implications of a Broad View of Information Literacy}

So what are the implications of this dual understanding of information for our advocacy of information literacy and the practice of information literacy instruction? Perhaps most significantly is the recognition that the domain of knowledge and skill involved in information literacy is much larger than previously imagined. When we begin to consider not only success in life and career, but the dual goals of personal and world transformation as the benchmarks of the information literate individual, we are no longer talking about discrete critical thinking skills or database searching skills. “Toto, I don't 
think we're in Kansas any more!" No, this is a more wondrous and imaginative information universe than we have worked with before. And librarians have a key role to play.

This broad view forces us to recognize once and for all that information literacy instruction is not a synonym for library instruction. In fact, this more robust conceptualization of information literacy not only raises questions about the nature of what librarians teach, but also what our faculty colleagues teach and how it is accomplished. Information literacy, thus conceived, is truly at the center of educational reform. Central to this notion is that evaluative information skills focused on concrete realities cannot effectively be taught in isolation from what is meaningful to students. We must teach both sides of information. If we want to teach critical thinking, we need to spend as much time ensuring that what we teach connects with students' inner life. It is not enough to simply pique the interest of students. As teachers, we must value the inner life and bring it fully into the classroom. We must find the source of continuous student inspiration and motivation.

Another implication is that teaching both sides of information requires rethinking library participation in the curriculum. This re-visioning argues for the necessary integration of a broad range of information skills into the curriculum, not just critical thinking and library skills, but life skills and personal information skills. No subject content can be effectively learned in isolation. Curriculum that exists as if we live strictly in a rational and concrete world makes no sense, is hardly rational at all. Do libraries have anything to offer to the process of teaching the other side of information? 
Libraries have a significant role to play in the educational reform movement which is occurring all around us, and which in turn is impacting the changing nature of academic libraries. Indeed, libraries will have an even larger role in the teaching of the other side of information, the teaching of this broader conception of information literacy. In fact, our organizations have always held, and provided access to, materials that bring the world into students' lives in a meaningful way. Our libraries retain the images, the world-views, the wisdom of the ages. We can provide students with the means to listen to Beethoven's Seventh Symphony and to view Michaelangelo's Sistene Chapel. We have more to bring to bear on the curriculum than critical thinking about information sources.

However, our framing of information literacy has not been presented in this manner. Typically, we have provided vast resources for the curriculum, but our foray into instruction has focused in a more limited manner on finding and evaluating information-more of the instrumental and technical approach. There is a great deal to be gained in terms of student learning by emphasizing the importance of the other side of information in our dialogues on campus. Libraries have such a tremendous capacity to bring the personally meaningful side of course content into the lives of students through our resources and technologies. Information literacy instruction can include multimedia productions and performance designed to dovetail with the intellectual content of a course. But valuing the other side of information both within the library and the curriculum is essential.

\section{Re-Visioning Listening and Collaboration}

Re-visioning information literacy means talking about it differently, and listening differently to others as well. This is another very important implication. When we talk to 
faculty about the library's curricular participation, we must emphasize the possibilities inherent in this broad information domain, and the repertoire of learning that far exceeds critical thinking alone. We must talk to faculty about supporting student engagement by bringing additional information into the classroom that elicits a personally meaningful response, and that permits students to understand themselves better through the content of the course.

Our relevance on campus will increasingly depend on our ability to listen more carefully to the way that disciplinary faculty talk about information, and to respond in kind. This is especially important for success as collaborators with faculty. Faculty approach libraries in a variety of manners, but they remain especially interested in the vast amounts of information they contain. They are not universally receptive to "critical thinking about information" as the library's most significant contribution to student learning. Faculty are frequently interested in ideas and possibilities and the connections between them. That is to say, they may also value intuitive insights, metaphorical links, and more expansive ways of knowing. More specifically, this view of information literacy will help librarians bridge the gap to faculty and humanities scholars who have a passion for the other side of information, and may be somewhat unimpressed by our single-minded focus on critical thinking about information.

In an earlier work, Dick Raspa and I discussed successful librarian and faculty collaboration as a way of being. ${ }^{18}$ Collaboration requires the ability to take risks in reaching out, and to approach each other with openness and wonder, and to practice listening without judging. When we listen with open hearts and minds to the ways others use information, we take the first steps in establishing authentic collaboration. Even if a 
certain style of information use may be unfamiliar to us, our willingness and curiosity alone can build the necessary bridge. However, we must want to learn, and ultimately, we must be lifelong learners.

Related to listening is our relationship to students. In order to help students become lifelong learners, we must not only help them understand themselves better. We must understand them as well, understand that their lives are more complicated than we can often appreciate. They do not turn off their lives when they step into our library session or class. We need to open the doors of communication, to be co-learners with them, to grow with them. We must live the reality that life is relationship, not about separation by role or department.

Perhaps the most profound implication of this revision of information literacy concerns the absolute necessity of integrating the library and its information sources into the curriculum. Teaching research skills has made this quite obvious for many years. The one-shot library session has never been an adequate approach to teaching and learning the research process. However, teaching both sides of information literacy--the one focused on logic and instrumental solutions, and the other on more personal and inward understandings—-makes one-shot instruction ludicrous.

As colleges and universities continue along the path of educational reform that enhances student learning, the library must become formally incorporated into new institutional structures. The boundaries presently separating the library from academic departments, and those separating librarians from faculty and students, will become more permeable. Librarians with a broad understanding of the two sides of information literacy 
will become partnered with classroom faculty, technologists, student affairs personnel and students in a seamlessly integrated curriculum.

All of this argues for the necessity of greater collaboration between librarians and classroom instructors. Teaching research skills without a meaningful context limits real learning. Creating such a context means integrating the other side of information literacy into the process. And this takes time.

The future of libraries and information literacy requires us to reexamine both what we teach and how it is structured within the curriculum. The current emphasis on strategies that enhance student learning is, in many ways, an indirect attempt to get at the other side of information literacy. Libraries have a great deal to offer within a paradigm focused on learning rather than teaching, especially regarding student curiosity, motivation and self-understanding.

I believe that such a re-visioning of information literacy would give birth to the future academic library - a place thoroughly integrated into the flow of campus learning where librarians, possessing diverse knowledge and expertise, would assist patrons in a multiplicity of information-related processes. These would include finding quality information, exploring the personal significance of a topic, framing an aesthetic experience of music, and facilitating personal awareness. Our area of expertise would be the entire field of information process, now taught in piecemeal fashion on our campuses.

\section{Conclusion}

There are two sides of information and two sides of information literacy. Ultimately, information literacy requires more than an impassive and objective working with the world. It requires that we are able to navigate through the internal realm as much 
as the external. If we lack self-understanding and an ability to accept the conjuring of our inner life, we can neither be effective in our lives or in the world. If we fail to develop our inner information capacities, we fail to become fully information literate.

Many of us contend that information literacy programs must be created to make a positive difference in the world. In order to do so, librarians must work with their colleagues across campus to define and live into the highest aspirations of education--to help students become transformed so that they might transform the world. Teaching both sides of information literacy will be a key to that future world. Growth in selfunderstanding and humanity is an inextricable part of growth in information literacy.

\section{Notes and References}

1. Final Report of the American Library Association Presidential Committee on Information Literacy, (Chicago: The Association, 1989).

2. Association of College and Research Libraries. Competency Standards for Information Literacy, (Chicago: The Association, 2001).

3. Association of College and Research Libraries. Characteristics of Information Literacy Programs Demonstrating Best Practices, (Chicago: The Association, 2003). 4. Loanne Snavely and Natasha Cooper, "Competing Agendas in Higher Education," Reference \& User Services Quarterly 37, no. 1 (Fall 1997): 53-62.

5. Robert B. Barr and John Tagg, "From Teaching to Learning—a New Paradigm for Undergraduate Education," Change, 27, no. 6 (November/December 1995): 12-25. 6. Good Will Hunting, Dir. Gus Van Sant. Perf. Matt Damon and Robin Williams. 1997. Videocassette. Miramax, 1998. 
7. Jeremy J. Shapiro and Shelley K. Hughes, "Information Literacy as a Liberal Art," Educom Review 31, no. 2 (March/April 1996): 31-35.

8. John M. Dirkx, "Nurturing Soul in Adult Learning," New Directions for Adult and Continuing Education, 74 (summer 1997), p. 79.

9. John Lennon and Paul McCartney, "With a Little Help from My Friends," Sergeant Pepper's Lonely Hearts Club Band. Perf. The Beatles. Capitol, 1967.

10. Neil Baldwin, "Book's Theme Came as a Revelation," Chicago Tribune, Section 14 (July 24, 2005), p. 3.

11. James Hillman, Inter Views, (New York: Harper \& Row, 1983), p. 55.

12. Rainer Maria Rilke, Letters to a Young Poet, (New York: Norton, 1993 [1934]), p.35.

13. Ibid, p. 2.

14. Richard Quinney, For the Time Being: Ethnography of Everyday Life. (Albany, NY:

State University of New York, 1998), p. 57.

15. Parker J. Palmer, The Courage to Teach: Exploring the Inner Landscape of a

Teacher's Life. (San Francisco, CA: Jossey-Bass, 1998).

16. Thomas Merton, The Other Side of the Mountain: The End of the Journey, Ed. Patrick Hart. (San Francisco, CA: HarperCollins, 1999), p. 54.

17. Black Eyed Peas and Justin Timberlake, "Where Is the Love," Elephunk. Perf. Black Eyed Peas with Justin Timberlake. A\&M, 2003.

18. Dick Raspa and Dane Ward, "Listening for Collaboration: Librarians and Faculty Working Together," The Collaborative Imperative: Librarians and Faculty Working Together in the Information Universe. Ed. D. Raspa and D. Ward. (Chicago, IL: Association of College and Research Libraries, 2000), pp. 1-18. 